\title{
PENGARUH TERAPI BERMAIN TERHADAP PERILAKU KOOPERATIF ANAK SELAMA TINDAKAN PROSEDUR INVASIF: LITERATURE REVIEW
}

\author{
Nur Rahmah', Tuti Seniwati², Bahtiar Bahtiar ${ }^{3}$ \\ ${ }^{123}$ Program Studi Ilmu Keperawatan, Fakultas Keperawatan, Universitas Hasanuddin. \\ Makassar, Indonesia \\ Email: tutiseniwati@gmail.com
}

\begin{abstract}
Abstrak
Rawat Inap seperti pelaksanaan prosedur invasif dapat mengganggu kehidupan anak dan menimbulkan perasaan seperti kecemasan, ketakutan dan perilaku tidak kooperatif. Salah satu intervensi keperawatan untuk meminimalisir dampak hospitalisasi pada anak usia 3-6 tahun yaitu dengan memberikan terapi bermain. Untuk mengetahui adanya pengaruh terapi bermain terhadap perilaku kooperatif anak selama tindakan invasif. Rancangan yang digunakan adalah Literature review. Studi Literature review ini berdasarkan PRISMA checklist. Pencarian artikel melalui 6 database. PubMed, SciELO, Science Direct, DOAJ, Portal Garuda, dan Wiley Online Library. Kata kunci yang digunakan saat pencarian berdasarkan database MeSH Term. Dari 12.102 artikel dari tahun 2010-2020 yang diidentifikasi didapatkan sebanyak 11 artikel yang sesuai dengan kriteria inklusi dan eksklusi. Penelitian tentang pengaruh terapi bermain terhadap perilaku kooperatif anak selama tindakan prosedur invasif menunjukkan bahwa terdapat 9 studi eksperimen dan 2 studi kuantitatif yang direview. Studi dilakukan di beberapa negara di dunia: 9 studi dilakukan di Indonesia, dan 2 studi di Brazil. Populasi yang diteliti adalah anak berumur 3-6 tahun. Namun paling banyak ditemui dalam literature review ini anak dengan jenis kelamin perempuan dan berusia 4 tahun. Sebagian besar penelitian menunjukkan intervensi dengan terapi bermain dapat meningkatkan perilaku kooperatif dan penerimaan prosedur invasif. Terapi bermain memiliki manfaat pada anakanak yang menjalani perawatan di rumah sakit dan berpengaruh terhadap perilaku kooperatif anak selama tindakan invasif.
\end{abstract}

Kata kunci: Perilaku kooperatif anak, Terapi bermain, tindakan invasif

\section{Abstract}

Background: Hospitalization such as carrying out invasive procedures can disrupt the child's life and can lead to feelings such as anxiety, fear and uncooperative behavior. One of the nursing interventions to minimize the impact of hospitalization on children aged 3-6 years is by providing play therapy one of. Purpose: This is to determine the effect of play therapy on children's cooperative behavior during invasive action. Method: The design used was a literature review. This literature review study is based on the PRISMA checklist. Search for articles through 6 databases. PubMed, SciELO, Science Direct, DOAJ, Portal Garuda, and Wiley Online Library. This study uses search keywords based on the MeSH Term database. Result: Of the 12,102 articles from 2010-2020 that were identified, 11 articles matched the inclusion and exclusion criteria. Research investigating the effect of play therapy on children's cooperative behavior during invasive procedures. There were 9 experimental studies and 2 quantitative studies. The study was conducted in several countries in the world: 9 studies were conducted in Indonesia and 2 studies were conducted in Brazil. The population studied was children aged 3-4 years. However, the most commonly found in this literature review are children with female sex and aged 4 years. Most research suggests that interventions with play therapy can improve cooperative behavior and acceptance of invasive procedures. Conclusion: Play therapy has a beneficial impact on the care of hospitalized children and greatly influences children's cooperative behavior during invasive procedures.

Keywords: Children's cooperative behavior, invasive measures, play therapy 
Nur Rahmah, Tuti Seniwati, dan Bahtiar, Pengaruh Terapi Bermain terhadap Perilaku Kooperatif Anak Selama Tindakan Prosedur Invasif: Literature Review

\section{PENDAHULUAN}

Hospitalisasi merupakan suatu rencana yang mengharuskan anak untuk tinggal di rumah sakit agar menjalani terapi dan perawatan. Selama proses tersebut anak dapat mengalami traumatik dan penuh dengan stress (Supartini, 2010). Hospitalisasi akan menyebabkan anak merasakan trauma jangka pendek maupun jangka panjang (Hockenberry \& Wilson, 2007). Masa hospitalisasi ini merupakan tahap yang berperan dalam proses penyembuhan pasien anak selama perawatan dan pengobatan di rumah sakit.

Angka kesakitan anak di Indonesia berdasarkan Survei Sosial Ekonomi Nasional (SUSENAS) tahun 2015 adalah 15,26\%. Angka kesakitan anak di daerah pedesaan sebesar 15,75\%, sementara angka kesakitan di daerah perkotaan sebesar 14,74\%. Angka kesakitan anak di Indonesia yang dirawat di rumah sakit cukup tinggi yaitu sekitar 35 per 100 anak, yang ditunjukkan dengan selalu penuhnya ruangan anak baik rumah sakit pemerintah maupun rumah sakit swasta. Tidak terdapat perbedaan yang signifikan antara angka kesakitan anak laki-laki 15,39\% dan anak perempuan 15,13\% (Terri \& Susan, 2015).

Berdasarkan Bucholz et al., (2019) jumlah pasien anak yang dirawat di Amerika mencapai 1 juta pada tahun 2016 menurun $21,3 \%$ dari 1,3 juta pasien pada tahun 2010 akan tetapi 3-10\% pasien anak yang dirawat di Amerika Serikat mengalami stres selama hospitalisasi. Sedangkan di Jerman, sekitar 3-7\% anak usia sekolah yang dirawat juga mengalami hal yang sama, 5-10\% anak yang dihospitalisasi di Kanada dan Selandia Baru juga mengalami stress selama hospitalisasi (WHO, 2012).

Penelitian Marsac dan Ph, (2017) melaporkan bahwa anak-anak akan mengalami berbagai stressor terkait cedera dan pengalaman di rumah sakit seperti tindakan medis atau prosedural. Pada umumnya anak-anak yang mengalami hospitalisasi sering kali mengalami perpisahan dengan orang tuanya, anak yang mengalami hospitalisasi harus dapat beradaptasi dengan lingkungan baru dan orang-orang di sekelilingnya, dampak dari ini anak dirawat dan hospitalisasi adalah ketakutan disekitarnya, kegelisahan, trauma dan cemas (Kartinawati et al., 2011). Gejala stress pasca trauma pada pasien yang dirawat di rumah sakit dengan kasus kecelakaan lebih banyak mengalami Hyperarousal/ gangguan emosional (Bahris et al., 2020).

Perilaku kooperatif anak selama dalam menjalani perawatan di rumah sakit sangat diperlukan untuk proses penyembuhan. Hasil penelitian Handayani dan Puspitasari (2010) melaporkan bahwa perilaku anak yang tidak kooperatif selama dirawat di 
rumah sakit dapat ditangani dengan melakukan terapi bermain. Bermain merupakan unsur yang berperan dalam proses perkembangan fisik, intelektual, emosi mental, sosial maupun kreativitas bagi anak (Soetjiningsih, 2014).

Penelitian oleh Mairiza (2015) mengenai efek terapi bermain terhadap perilaku kooperatif anak selama hospitalisasi diperoleh data bahwa sebelum intervensi, terdapat sekitar $80 \%$ anak tidak kooperatif dalam perawatan dan setelah intervensi dilakukan, sebagian besar anak atau sebesar 90\% menjadi kooperatif. Dari penelitian ini dapat disimpulkan bahwa pemberian terapi bermain dapat membuat anak usia pra sekolah menjadi kooperatif selama menjalani perawatan.

Selama hospitalisasi, terapi bermain terbukti memiliki nilai terapeutik yang tinggi bagi anak-anak yang sakit sehingga memberikan kontribusi untuk kesejahteraan fisik dan emosional mereka serta mengurangi perasaan negatif selama hospitalisasi. Selain itu, bermain banyak digunakan dalam persiapan pra operasi dan prosedur invasif (Koukourikos et al., 2015).

\section{METODE PENELITIAN}

Penelitian ini menggunakan metode Literature review. Literature review merupakan cara yang digunakan untuk mengumpulkan data atau informasi yang berkaitan dengan pengaruh atau efek terapi bermain terhadap perilaku kooperatif anak selama tindakan invasif. Artikel ini ditulis menggunakan PRISMA checklist (Moher et al., 2009).

Pencarian dilakukan secara komprehensif dalam studi yang diterbitkan dari tahun 2010-2020 menggunakan database PubMed, SciELO, DOAJ, Portal Garuda, Sciencedirect dan Wiley Online Library. Bahasa yang digunakan dalam melakukan pencarian artikel yaitu bahasa Indonesia dan Inggris. Pencarian dilakukan menggunakan Search Engine pada Mozilla Firefox versi 80.0.1 dan Google Chrome versi 81.0.4044.138 yang dikombinasikan dengan Mendeley Importer. Melalui Mendeley Desktop versi 1.19.4 akan dilakukan duplikasi serta skrining judul dan abstrak. Artikel yang didapat dan sesuai dengan kriteria inklusi dan eksklusi didownload atau di ambil untuk selanjutnya dilakukan analisis.

Semua artikel pencarian dibatasi pada artikel jurnal yang full text, dalam bahasa Indonesia dan bahasa Inggris, penelitian murni (non literature, protokol studi), usia 3-6 tahun. 
Nur Rahmah, Tuti Seniwati, dan Bahtiar, Pengaruh Terapi Bermain terhadap Perilaku Kooperatif Anak Selama Tindakan Prosedur Invasif: Literature Review

\section{SELEKSI STUDI}

Berdasarkan penelusuran artikel dengan menggunakan database PubMed, SciELO, DOAJ, Portal Garuda, Sciencedirect dan Wiley Online Library, maka kata kunci yang dipakai adalah: "terapi bermain" dan "anak" atau "prasekolah" dan "perilaku kooperatif" dan "prosedur invasif" dan "hospitalisasi" atau "play therapy" $O R$ "therapeutic play" AND "children” OR "Preschool" AND "cooperative behavior" AND "invasive procedure" AND "hospitalization". Peneliti menemukan pada database PubMed ditemukan sebanyak 1.524 artikel. Pada database SciELO ditemukan sebanyak 3 artikel. Pada database Science Direct ditemukan 2.863 artikel. Pada database DOAJ ditemukan sebanyak 17 artikel. Pada database Wiley Online Library 9,180 artikel. Pada database Portal Garuda ditemukan 5 artikel Bagan 1: Flow chart penelusuran literatur.

\section{HASIL PENELITIAN}

Dari 12,102 artikel yang diidentifikasi, diperoleh data sebanyak 11 artikel yang memenuhi kriteria inklusi, kesebelas artikel tersebut merupakan studi yang akan ditinjau dalam literature review ini. Semua artikel merupakan studi kuantitatif dan studi eksperimental. Studi ini dilakukan di berbagai Negara di seluruh dunia. Sembilan studi dilakukan di Indonesia dan dua studi di Brazil.

Populasi yang diteliti dalam studi ini merupakan anak yang berusia 3-6 tahun dengan jumlah sampel dari 9 hingga 60 pasien anak. Lokasi penelitian pada studi ini yaitu RS. Pelamonia Makassar, Ruang Seruni RSUD Jombang, Rawat Inap RSUD Siti Aisyah, RS Mitra Keluarga, RS. Airlangga Jombang, Ruang Edelweist RSUD DR. M Yunus Bengkulu, RS. Israelita Albert Einstein, Rumah Sakit Infatil Darcy Vargas di Kota Sao Paulo Brazil, Rumah Sakit Swasta Sistem Kesehatan Terpadu (SUS) di Kota Crato Brazil. Berikut Sintesis Grid Review Artikel (Tabel 1) 
Tabel 1.

Sintesis grid review artikel

\begin{tabular}{|c|c|c|c|c|c|c|c|}
\hline No & $\begin{array}{c}\text { Judul (Penulis, } \\
\text { (Tahun)/ } \\
\text { Negara }\end{array}$ & $\begin{array}{l}\text { Jumlah } \\
\text { sampel/ } \\
\text { Usia }\end{array}$ & Tujuan & $\begin{array}{l}\text { Kelompok } \\
\text { Intervensi }\end{array}$ & $\begin{array}{c}\text { Kelompok } \\
\text { Kontrol }\end{array}$ & $\begin{array}{l}\text { Desain } \\
\text { dan } \\
\text { Metode }\end{array}$ & Hasil \\
\hline 1. & $\begin{array}{l}\text { Pengaruh terapi } \\
\text { bermain boneka } \\
\text { terhadap } \\
\text { perilaku } \\
\text { kooperatif anak } \\
\text { selama } \\
\text { menjalani } \\
\text { perawatan di } \\
\text { ruangan Rawat } \\
\text { Inap Anak } \\
\text { (Elviani, 2019)/ } \\
\text { Indonesia }\end{array}$ & $\begin{array}{l}\text { Terdiri } \\
\text { dari } 33 \\
\text { sampel } \\
\text { berusia } \\
3-6 \\
\text { tahun. } \\
\text { Hanya } \\
\text { terdapat } \\
\text { kelompo } \\
\text { k } \\
\text { intervens } \\
\text { i tanpa } \\
\text { kelompo } \\
\text { k kontrol }\end{array}$ & $\begin{array}{l}\text { Tujuan } \\
\text { penelitian } \\
\text { yaitu untuk } \\
\text { mengidentif } \\
\text { ikasi efek } \\
\text { terapi } \\
\text { bermain } \\
\text { boneka } \\
\text { terhadap } \\
\text { perilaku } \\
\text { kooperatif } \\
\text { anak selama } \\
\text { dalam } \\
\text { perawatan } \\
\text { dan } \\
\text { pengobatan } \\
\text { di rumah } \\
\text { sakit. }\end{array}$ & $\begin{array}{l}\text { Kelompok } \\
\text { intervensi } \\
\text { diberikan } \\
\text { perlakuan atau } \\
\text { terapi bermain } \\
\text { dengan jenis } \\
\text { permainan } \\
\text { terapi boneka. }\end{array}$ & -- & $\begin{array}{l}\text { Quasi } \\
\text { Experimen } \\
\text { tal/ lembar } \\
\text { observasi }\end{array}$ & $\begin{array}{l}\text { 1. } \text { Karakteristik } \\
\text { a. Jenis kelamin } \\
\text { Laki-laki }=13(39,4 \%) \\
\text { Perempuan = } 20 \text { orang }(60,6 \%) \\
\text { b. Usia } \\
\text { Umur } 3 \text { tahun }=24,2 \%, \\
\text { Umur } 4 \text { tahun }=48,5 \% \\
\text { Umur } 5 \text { tahun }=9,1 \% \\
\text { Umur } 6 \text { tahun }=18,2 \% \\
\text { 2. Sesudah tindakan sebagian } \\
\text { besar responden perilaku } \\
\text { kooperatif }>60 \% \text { sebanyak } 33 \\
\text { responden }(100 \%)\end{array}$ \\
\hline 2. & $\begin{array}{l}\text { Terapi Bermain } \\
\text { terhadap } \\
\text { perilaku } \\
\text { kooperatif pada } \\
\text { anak usia } \\
\text { pra sekolah } \\
\text { (Apriani, 2017)/ } \\
\text { Indonesia }\end{array}$ & $\begin{array}{l}30 \\
\text { sampel/3 } \\
-6 \text { tahun. } \\
\text { Hanya } \\
\text { terdiri } \\
\text { kelompo } \\
\text { k } \\
\text { intervens } \\
\text { i tanpa } \\
\text { kelompo } \\
\text { k kontrol }\end{array}$ & $\begin{array}{l}\text { Penelitian } \\
\text { ini } \\
\text { bertujuan } \\
\text { untuk } \\
\text { mengidentif } \\
\text { ikasi efek } \\
\text { dari terapi } \\
\text { bermain } \\
\text { dengan } \\
\text { teknik } \\
\text { bercerita } \\
\text { terhadap } \\
\text { dampak } \\
\text { perilaku } \\
\text { kooperatif } \\
\text { anak usia } \\
\text { prasekolah. }\end{array}$ & $\begin{array}{l}\text { Kelompok } \\
\text { intervensi } \\
\text { mendapatkan } \\
\text { intervensi } \\
\text { tertentu dengan } \\
\text { keadaan yang } \\
\text { dapat dikontrol. } \\
\text { Diberikan terapi } \\
\text { bermain dengan } \\
\text { teknik bercerita. }\end{array}$ & -- & $\begin{array}{l}\text { Pra- } \\
\text { eksperime } \\
\text { ntal/lembar } \\
\text { observasi }\end{array}$ & $\begin{array}{l}\text { 1. Karakteristik } \\
\text { a. Jenis kelamin } \\
\text { Laki-laki }=12 \text { orang }(40,0 \%) \\
\text { Perempuan = } 18 \text { orang }(60 \%) \\
\text { b. Usia } \\
\text { Umur } 3 \text { tahun }=23,3 \% \\
\text { Umur } 4 \text { tahun }=33,3 \% \\
\text { Umur } 5 \text { tahun }=23,3 \% \\
\text { Umur } 6 \text { tahun }=20,0 \% \\
\text { 2. Sesudah dilakukan terapi } \\
\text { bermain sebanyak } 7 \text { orang yang } \\
\text { bersifat tidak kooperatif }(23,3 \% \text {, } \\
\text { dan sebanyak } 18 \text { orang }(60 \%), \\
\text { yang bersifat kooperatif } \\
\text { sedangkan } 5 \text { orang yang bersifat } \\
\text { sangat kooperatif }(16,7 \%) .\end{array}$ \\
\hline 3. & $\begin{array}{l}\text { Pengaruh terapi } \\
\text { bermain } \\
\text { terhadap tingkat } \\
\text { kooperatif anak } \\
\text { usia prasekolah } \\
\text { (Purna et al., } \\
\text { 2016) / } \\
\text { Indonesia }\end{array}$ & $\begin{array}{l}14 \\
\text { sampel } \\
\text { berusia } \\
4-6 \\
\text { tahun. } \\
\text { Hanya } \\
\text { terdiri } \\
\text { kelompo } \\
\mathrm{k} \\
\text { intervens } \\
\text { i tanpa } \\
\text { kelompo } \\
\text { k kontrol }\end{array}$ & $\begin{array}{l}\text { Penelitian } \\
\text { ini } \\
\text { bertujuan } \\
\text { menganalisi } \\
\text { s pengaruh } \\
\text { terapi } \\
\text { bermain } \\
\text { terhadap } \\
\text { tingkat } \\
\text { kooperatif } \\
\text { anak usia } \\
\text { prasekolah. }\end{array}$ & $\begin{array}{l}\text { Kelompok } \\
\text { intervensi } \\
\text { dilakukan } \\
\text { dengan cara } \\
\text { mengambil } \\
\text { populasi yang } \\
\text { memenuhi } \\
\text { kriteria yang } \\
\text { telah ditentukan } \\
\text { peneliti. } \\
\text { Penelitian ini } \\
\text { dilakukan terapi } \\
\text { bermain } \\
\text { mewarnai } \\
\text { gambar. }\end{array}$ & -- & $\begin{array}{l}\text { Pra- } \\
\text { eksperime } \\
\text { ntal/kemba } \\
\text { r observasi }\end{array}$ & $\begin{array}{l}\text { 1. Karakteristik } \\
\text { a. Jenis kelamin } \\
\text { Laki-laki }=9 \text { orang atau } 64,3 \% \\
\text { Perempuan }=5 \text { orang atau } \\
35,7 \% \\
\text { b. Usia } \\
\quad \text { Umur } 4 \text { tahun }=28,6 \% \\
\text { Umur } 5 \text { tahun }=42,9 \% \\
\text { Umur } 6 \text { tahun }=28,6 \% \\
\text { 2. Sebagian besar }(71,4 \%) \\
\text { responden dengan tingkat } \\
\text { kooperatif negatif sebelum } \\
\text { perlakuan terapi bermain sebanyak } \\
\text { 10 responden. Hampir seluruhnya } \\
\text { (78,6\%) responden dengan tingkat } \\
\text { kooperatif yang positif sesudah } \\
\text { perlakuan terapi bermain. }\end{array}$ \\
\hline
\end{tabular}


Nur Rahmah, Tuti Seniwati, dan Bahtiar, Pengaruh Terapi Bermain terhadap Perilaku Kooperatif Anak Selama Tindakan Prosedur Invasif: Literature Review

\begin{tabular}{|c|c|c|c|c|c|c|c|}
\hline No & $\begin{array}{c}\text { Judul (Penulis, } \\
\text { (Tahun)/ } \\
\text { Negara }\end{array}$ & $\begin{array}{l}\text { Jumlah } \\
\text { sampel/ } \\
\text { Usia }\end{array}$ & Tujuan & $\begin{array}{l}\text { Kelompok } \\
\text { Intervensi }\end{array}$ & $\begin{array}{c}\text { Kelompok } \\
\text { Kontrol }\end{array}$ & $\begin{array}{c}\text { Desain } \\
\text { dan } \\
\text { Metode }\end{array}$ & Hasil \\
\hline 4. & $\begin{array}{l}\text { Pengaruh terapi } \\
\text { bermain } \\
\text { terhadap } \\
\text { tindakan } \\
\text { kooperatif anak } \\
\text { usia 3-5 tahun } \\
\text { dalam } \\
\text { menjalani } \\
\text { perawatan di } \\
\text { ruangan anak } \\
\text { (Andriany, } \\
\text { 2018)/Indonesia }\end{array}$ & $\begin{array}{l}30 \\
\text { sampel } \\
\text { berusia } \\
3-5 \\
\text { tahun. } \\
\text { Terdapat } \\
\text { kelompo } \\
\mathrm{k} \\
\text { perlakua } \\
\text { n tanpa } \\
\text { kelompo } \\
\text { k kontrol }\end{array}$ & $\begin{array}{l}\text { Tujuan } \\
\text { penelitian } \\
\text { adalah } \\
\text { untuk } \\
\text { melihat } \\
\text { pengaruh } \\
\text { terapi } \\
\text { bermain } \\
\text { terhadap } \\
\text { tindakan } \\
\text { kooperatif } \\
\text { anak yang } \\
\text { berusia 3-5 } \\
\text { tahun } \\
\text { selama } \\
\text { dalam } \\
\text { perawatan } \\
\text { di ruang } \\
\text { anak. }\end{array}$ & $\begin{array}{l}\text { Kelompok } \\
\text { intervensi } \\
\text { dilakukan } \\
\text { sesuai dengan } \\
\text { kriteria inklusi. } \\
\text { Diberi } \\
\text { perlakuan } \\
\text { dengan } \\
\text { diberikan terapi } \\
\text { bermain } \\
\text { mewarnai, } \\
\text { berbicara, dan } \\
\text { menggambar. }\end{array}$ & -- & $\begin{array}{l}\text { Studi } \\
\text { Eksperime } \\
\text { n/lembar } \\
\text { kuesioner }\end{array}$ & $\begin{array}{l}\text { 1. Karakteristik } \\
\text { a. Jenis kelamin } \\
\text { Laki-laki }=16 \text { orang }(53,3 \%) \\
\text { Perempuan }=14 \text { orang }(46,7 \%) \\
\text { b. Usia } \\
\text { Umur } 3 \text { tahun }=43,4 \% \\
\text { Umur } 4 \text { tahun }=36,7 \% \\
\text { Umur } 5 \text { tahun }=20,0 \% \\
\text { 2. Perilaku kooperatif } \\
\text { - Mewarnai sebanyak } 14(46,7 \%) \\
\text { responden yang kooperatif, dan } \\
\text { sebanyak } 15(53,3 \%) \text { responden } \\
\text { yang tidak kooperatif. } \\
\text { - Bercerita sebanyak } 22 \text { orang } \\
\text { ( } 73,3 \%) \text { yang kooperatif, } \\
\text { sebanyak } 8 \text { orang }(26,7 \%) \text { yang } \\
\text { tidak kooperatif. } \\
\text { - Menggambar sebanyak } 16 \\
\text { orang (53,3\%) yang kooperatif, } \\
\text { dan sebanyak } 14 \text { orang ( } 46,7 \%) \\
\text { yang tidak kooperatif. }\end{array}$ \\
\hline
\end{tabular}

\begin{tabular}{|c|c|c|c|c|c|c|}
\hline 5. & $\begin{array}{l}\text { Pengaruh terapi } \\
\text { bermain } \\
\text { terhadap } \\
\text { perilaku } \\
\text { kooperatif } \\
\text { dalam asuhan } \\
\text { keperawatan } \\
\text { anak usia } \\
\text { prasekolah di } \\
\text { ruang anak } \\
\text { (TAT \& SING, } \\
\text { 2014)/Indonesia }\end{array}$ & $\begin{array}{l}32 \\
\text { sampel/3 } \\
-5 \text { tahun. } \\
\text { Hanya } \\
\text { terdiri } \\
\text { kelompo } \\
\mathrm{k} \\
\text { intervens } \\
\text { i tanpa } \\
\text { ada } \\
\text { kelompo } \\
\mathrm{k} \\
\text { pemband } \\
\text { ing } \\
\text { (kontrol). }\end{array}$ & $\begin{array}{l}\text { Penelitian } \\
\text { ini } \\
\text { bertujuan } \\
\text { untuk } \\
\text { mengetahui } \\
\text { pengaruh } \\
\text { terapi } \\
\text { bermain } \\
\text { terhadap } \\
\text { perilaku } \\
\text { kooperatif } \\
\text { anak }\end{array}$ & $\begin{array}{l}\text { Kelompok } \\
\text { intervensi } \\
\text { ditentukan } \\
\text { berdasarkan } \\
\text { kriteria inklusi. } \\
\text { Perlakuan yang } \\
\text { diberikan yaitu } \\
\text { dengan terapi } \\
\text { bermain dengan } \\
\text { menggunakan } \\
\text { alat kedokteran. }\end{array}$ & -- & $\begin{array}{l}\text { Pra- } \\
\text { eksperime } \\
\text { n/ lembar } \\
\text { observasi }\end{array}$ \\
\hline
\end{tabular}

1. Karakteristik

a. Jenis kelamin

Laki-laki $=15$ orang $(46,9 \%)$

Perempuan $=17$ orang $(53,1 \%)$

b. Usia

Umur 3 tahun $=34,4 \%$

Umur 4 tahun $=50,0 \%$

Umur 5 tahun $=15,6 \%$

Persentase perilaku kooperatif anak setelah diberikan terapi bermain adalah sangat kooperatif (100\%)

\begin{tabular}{|c|c|c|c|c|c|}
\hline $\begin{array}{l}\text { Therapeutic } \\
\text { play: preparing } \\
\text { the child for the } \\
\text { vaccine (Pontes } \\
\text { et al., 2015) } \\
\text { /Brazil }\end{array}$ & $\begin{array}{l}60 \\
\text { sampel/3 } \\
-6 \text { tahun. } \\
\text { Kelompo } \\
\text { k } \\
\text { intervens } \\
\text { i dan } \\
\text { kelompo } \\
\text { k kontrol } \\
\text { dipilih } \\
\text { secara } \\
\text { acak } \\
\text { sesuai } \\
\text { kriteria } \\
\text { inklusi }\end{array}$ & $\begin{array}{l}\text { Tujuan } \\
\text { penelitian } \\
\text { ini untuk } \\
\text { mengidentif } \\
\text { ikasi dan } \\
\text { membandin } \\
\text { gkan } \\
\text { perilaku } \\
\text { anak-anak } \\
\text { selama } \\
\text { prosedur } \\
\text { invasif. }\end{array}$ & $\begin{array}{l}\text { Kelompok } \\
\text { intervensi } \\
\text { adalah pasien } \\
\text { yang menerima } \\
\text { intervensi terapi } \\
\text { bermain }\end{array}$ & $\begin{array}{l}\text { Kelompok } \\
\text { kontrol } \\
\text { akan } \\
\text { mendapatka } \\
\mathrm{n} \text { persiapan } \\
\text { rutin tetapi } \\
\text { tidak } \\
\text { mendapatka } \\
\mathrm{n} \text { intervensi }\end{array}$ & $\begin{array}{l}\text { Quasi } \\
\text { experiment } \\
\text { al }\end{array}$ \\
\hline
\end{tabular}

Reaksi utama pada kelompok eksperimen

adalah diam $(25 ; 83 \%)$ dan secara spontan berkolaborasi $(24 ; 80 \%)$.

Pada kelompok kontrol,

reaksi utama adalah tangisan dan kemelekatan pada orang tua (15; $50 \%)$, kemerahan $(11 ; 36,67 \%)$ dan gerakan tubuh / gelisah (10; $33,3 \%$ ). 


\begin{tabular}{|c|c|c|c|c|c|c|c|}
\hline No & $\begin{array}{c}\text { Judul (Penulis, } \\
\text { (Tahun)/ } \\
\text { Negara }\end{array}$ & $\begin{array}{c}\text { Jumlah } \\
\text { sampel/ } \\
\text { Usia }\end{array}$ & Tujuan & $\begin{array}{l}\text { Kelompok } \\
\text { Intervensi }\end{array}$ & $\begin{array}{c}\text { Kelompok } \\
\text { Kontrol }\end{array}$ & $\begin{array}{c}\text { Desain } \\
\text { dan } \\
\text { Metode }\end{array}$ & Hasil \\
\hline 7. & $\begin{array}{l}\text { Pengaruh terapi } \\
\text { bermain kolase } \\
\text { kartun terhadap } \\
\text { tingkat } \\
\text { kooperatif anak } \\
\text { usia prasekolah } \\
\text { selama } \\
\text { prosedur } \\
\text { nebulizer di } \\
\text { rumah sakit } \\
\text { Airlangga } \\
\text { Jombang } \\
\text { (Ningrum \& } \\
\text { Nasrudin, } \\
\text { 2015)/Indonesia }\end{array}$ & $\begin{array}{l}20 \\
\text { sampel/3 } \\
-6 \text { tahun. } \\
\text { Kelompo } \\
\mathrm{k} \\
\text { intervens } \\
\mathrm{i} \\
\text { berjumla } \\
\text { h } 10 \\
\text { sampel } \\
\text { dan } \\
\text { kelompo } \\
\text { k kontrol } \\
10 \\
\text { sampel. }\end{array}$ & $\begin{array}{l}\text { Penelitian } \\
\text { ini } \\
\text { bertujuan } \\
\text { untuk } \\
\text { mengidentif } \\
\text { ikasi efek } \\
\text { dari terapi } \\
\text { bermain } \\
\text { kolase } \\
\text { kartun } \\
\text { terhadap } \\
\text { tingkat } \\
\text { kooperatif } \\
\text { anak. }\end{array}$ & $\begin{array}{l}\text { Kelompok } \\
\text { intervensi } \\
\text { adalah pasien } \\
\text { yang menerima } \\
\text { intervensi terapi } \\
\text { bermain kolase } \\
\text { kartun. }\end{array}$ & $\begin{array}{l}\text { Kelompok } \\
\text { kontrol } \\
\text { akan } \\
\text { mendapatka } \\
\mathrm{n} \text { persiapan } \\
\text { rutin tetapi } \\
\text { tidak } \\
\text { mendapatka } \\
\mathrm{n} \text { intervensi }\end{array}$ & $\begin{array}{l}\text { Quasi } \\
\text { Experimen } \\
\text { tal/ lembar } \\
\text { observasi }\end{array}$ & $\begin{array}{l}\text { 1. Karakteristik } \\
\text { a.Jenis kelamin } \\
\text { Laki-laki }=4(40 \%) \\
\text { Perempuan }=6(60 \%) \\
\text { b. Usia } \\
\text { Umur } 3 \text { tahun }=20 \% \\
\text { Umur } 4 \text { tahun }=40 \% \\
\text { Umur } 5 \text { tahun }=30 \% \\
\text { Umur } 6 \text { tahun }=10 \% \\
\text { Kelompok intervensi } 1 \text { mempunyai } \\
\text { porsi yang tingkat kooperatif } 60 \% \\
\text { dan kelompok kontrol tingkat } \\
\text { kooperatifnya sebesar } 40 \% \text {. }\end{array}$ \\
\hline 8. & $\begin{array}{l}\text { Pengaruh terapi } \\
\text { bermain ular } \\
\text { tangga terhadap } \\
\text { tingkat } \\
\text { kooperatif anak } \\
\text { prasekolah } \\
\text { selama } \\
\text { menjalankan } \\
\text { perawatan } \\
\text { (Colin et al., } \\
\text { 2020)/Indonesia }\end{array}$ & $\begin{array}{l}20 \\
\text { sampel/3 } \\
-6 \text { tahun. } \\
\text { Hanya } \\
\text { terdiri } \\
\text { kelompo } \\
\text { k } \\
\text { intervens } \\
\text { i tanpa } \\
\text { ada } \\
\text { kelompo } \\
\text { k kontrol }\end{array}$ & $\begin{array}{l}\text { Penelitian } \\
\text { ini } \\
\text { bertujuan } \\
\text { untuk } \\
\text { mengidentif } \\
\text { ikasi } \\
\text { pengaruh } \\
\text { terapi } \\
\text { bermain } \\
\text { ular tangga } \\
\text { terhadap } \\
\text { tingkat } \\
\text { kooperatif } \\
\text { anak } \\
\text { prasekolah } \\
\text { selama } \\
\text { menjalani } \\
\text { perawatan. }\end{array}$ & $\begin{array}{l}\text { Kelompok } \\
\text { intervensi } \\
\text { diberikan } \\
\text { perlakuan } \\
\text { dengan cara } \\
\text { terapi bermain } \\
\text { permainan ular } \\
\text { tangga. }\end{array}$ & -- & $\begin{array}{l}\text { Pre- } \\
\text { experiment } \\
\text { al/ } \\
\text { observasi }\end{array}$ & $\begin{array}{l}\text { 1. Sebelum intervensi, tingkat } \\
\text { kooperatif anak adalah } 44,55 \% \\
\text { 2. Setelah intervensi, tingkat } \\
\text { kooperatif anak meningkat } \\
\text { menjadi } 70,15 \%\end{array}$ \\
\hline 9. & $\begin{array}{l}\text { Pemberian } \\
\text { terapi bermain } \\
\text { dengan teknik } \\
\text { bercerita } \\
\text { terhadap } \\
\text { kooperatif anak } \\
\text { usia prasekolah } \\
\text { (Jafri, } \\
\text { 2015)/Indonesia }\end{array}$ & $\begin{array}{l}30 \\
\text { sampel/3 } \\
-6 \text { tahun. } \\
\text { Kelompo } \\
\text { k } \\
\text { intervens } \\
\text { i } \\
\text { berjumla } \\
\text { h } 15 \\
\text { orang } \\
\text { dan } \\
\text { kelompo } \\
\text { k kontrol } \\
\text { sebanyak } \\
15 \text { orang. }\end{array}$ & $\begin{array}{l}\text { Penelitian } \\
\text { ini } \\
\text { bertujuan } \\
\text { untuk } \\
\text { mengetahui } \\
\text { hubungan } \\
\text { antara terapi } \\
\text { bermain } \\
\text { dengan } \\
\text { menggunak } \\
\text { an teknik } \\
\text { bercerita } \\
\text { terhadap } \\
\text { perilaku } \\
\text { kooperatif } \\
\text { anak. }\end{array}$ & $\begin{array}{l}\text { Kelompok } \\
\text { intervensi } \\
\text { menggunakan } \\
\text { teknik bercerita } \\
\text { dalam } \\
\text { pelaksanaan } \\
\text { terapi bermain }\end{array}$ & $\begin{array}{l}\text { Kelompok } \\
\text { kontrol } \\
\text { tidak } \\
\text { mendapatka } \\
\text { n perlakuan } \\
\text { teknik } \\
\text { bercerita } \\
\text { dalam } \\
\text { terapi } \\
\text { bermain. }\end{array}$ & $\begin{array}{l}\text { Quasi } \\
\text { experiment } \\
\text { al/lembar } \\
\text { observasi }\end{array}$ & $\begin{array}{l}\text { Pada kelompok intervensi, terdapat } \\
\text { sebesar } 66,7 \% \text { responden yang } \\
\text { kooperatif setelah diberikan terapi } \\
\text { bermain dengan tehnik bercerita. } \\
\text { Sedangkan pada kelompok kontrol } \\
\text { hanya sebesar } 20 \% \text { yang kooperatif. }\end{array}$ \\
\hline
\end{tabular}


Nur Rahmah, Tuti Seniwati, dan Bahtiar, Pengaruh Terapi Bermain terhadap Perilaku Kooperatif Anak Selama Tindakan Prosedur Invasif: Literature Review

\begin{tabular}{|c|c|c|c|c|c|c|c|}
\hline No & $\begin{array}{c}\text { Judul (Penulis, } \\
\text { (Tahun)/ } \\
\text { Negara }\end{array}$ & $\begin{array}{c}\text { Jumlah } \\
\text { sampel/ } \\
\text { Usia }\end{array}$ & Tujuan & $\begin{array}{l}\text { Kelompok } \\
\text { Intervensi }\end{array}$ & $\begin{array}{c}\text { Kelompok } \\
\text { Kontrol }\end{array}$ & $\begin{array}{c}\text { Desain } \\
\text { dan } \\
\text { Metode }\end{array}$ & Hasil \\
\hline 10. & $\begin{array}{l}\text { Use of } \\
\text { therapeutic } \\
\text { play in } \\
\text { preparing } \\
\text { preschool } \\
\text { children for } \\
\text { outpatient } \\
\text { chemotherapy } \\
\text { (Artilheiro et } \\
\text { al., 2011)/Brazil }\end{array}$ & $\begin{array}{l}30 \\
\text { sampel } \\
\text { anak/3-6 } \\
\text { tahun. }\end{array}$ & $\begin{array}{l}\text { Penelitian } \\
\text { ini memiliki } \\
\text { tujuan yaitu } \\
\text { untuk } \\
\text { mendeskrips } \\
\text { ikan } \\
\text { penggunaan } \\
\text { terapi } \\
\text { bermain } \\
\text { dalam } \\
\text { mempersiap } \\
\text { kan anak } \\
\text { prasekolah } \\
\text { untuk } \\
\text { menjalani } \\
\text { kemoterapi } \\
\text { secara rawat } \\
\text { jalan }\end{array}$ & $\begin{array}{l}\text { Terapi bermain } \\
\text { diterapkan pada } \\
\text { anak-anak yang } \\
\text { menjalani } \\
\text { pengobatan } \\
\text { kemoterapi } \\
\text { rawat jalan. } \\
\text { Sebelum } \\
\text { pemberian obat, } \\
\text { anak diajak } \\
\text { bermain dengan } \\
\text { boneka } \\
\text { dan bahan yang } \\
\text { digunakan } \\
\text { dalam } \\
\text { kemoterapi } \\
\text { (kateter IV, } \\
\text { kapas, jarum } \\
\text { suntik. } \\
\text { Peneliti } \\
\text { menunjukkan } \\
\text { prosedur } \\
\text { kemoterapi } \\
\text { anak sambil } \\
\text { menceritakan } \\
\text { cerita dan } \\
\text { mengundang } \\
\text { mereka untuk } \\
\text { mengulang } \\
\text { permainan. } \\
\text { Durasi sesi } \\
\text { tidak } \\
\text { ditentukan. } \\
\end{array}$ & -- & $\begin{array}{l}\text { Quantitate } \\
\text { ve study }\end{array}$ & $\begin{array}{l}\text { Setelah intervensi, anak-anak } \\
\text { menunjukkan hasil sikap yang } \\
\text { positif, bekerja sama dengan } \\
\text { prosedur dan dengan staf kesehatan, } \\
\text { membangun hubungan kepercayaan } \\
\text { dengan mereka, menghadirkan } \\
\text { suasana santai dan tersenyum } \\
\text { selama prosedur }\end{array}$ \\
\hline 11. & $\begin{array}{l}\text { Therapeutic toy } \\
\text { during the } \\
\text { procedure of } \\
\text { venipuncture: A } \\
\text { strategy to } \\
\text { reduce } \\
\text { behavioral } \\
\text { changes } \\
\text { (Santiago et al., } \\
\text { 2016) / Brazil }\end{array}$ & $\begin{array}{l}21 \\
\text { sampel/3 } \\
-6 \text { tahun. }\end{array}$ & $\begin{array}{l}\text { Penelitian } \\
\text { ini memiliki } \\
\text { tujuan yaitu } \\
\text { untuk } \\
\text { membandin } \\
\text { gkan } \\
\text { perilaku } \\
\text { yang } \\
\text { ditunjukkan } \\
\text { oleh anak } \\
\text { saat } \\
\text { mempersiap } \\
\text { kan } \\
\text { venipunctur } \\
\text { e sebelum } \\
\text { dan sesudah } \\
\text { menggunak } \\
\text { an terapi } \\
\text { bermain. }\end{array}$ & $\begin{array}{l}\text { Perilaku anak- } \\
\text { anak selama } \\
\text { tusukan vena } \\
\text { diamati. } \\
\text { Selanjutnya } \\
\text { dilakukan sesi } \\
\text { terapi bermain } \\
\text { bersama anak- } \\
\text { anak } \\
\text { mensimulasikan } \\
\text { tusukan vena } \\
\text { pada boneka, } \\
\text { dan kemudian } \\
\text { mengulangi } \\
\text { prosedur dan } \\
\text { mengungkapkan } \\
\text { keraguan } \\
\text { mereka. Durasi } \\
\text { terapi bermain }\end{array}$ & -- & $\begin{array}{l}\text { Quantitati } \\
\text { ve study }\end{array}$ & $\begin{array}{l}\text { Intervensi dievaluasi dengan } \\
\text { mengamati reaksi anak-anak. } \\
\text { Setelah sesi terapi bermain, } \\
\text { ada peningkatan variabel } \\
\text { yang mengekspresikan adaptasi } \\
\text { yang lebih besar dan penerimaan } \\
\text { terhadap prosedur seperti berteriak, } \\
\text { ketegangan otot atau menangis }\end{array}$ \\
\hline
\end{tabular}




\begin{tabular}{|c|c|c|c|c|c|c|c|}
\hline No & $\begin{array}{c}\text { Judul (Penulis, } \\
\text { (Tahun)/ } \\
\text { Negara }\end{array}$ & $\begin{array}{c}\text { Jumlah } \\
\text { sampel/ } \\
\text { Usia }\end{array}$ & Tujuan & $\begin{array}{l}\text { Kelompok } \\
\text { Intervensi }\end{array}$ & $\begin{array}{c}\text { Kelompok } \\
\text { Kontrol }\end{array}$ & $\begin{array}{c}\text { Desain } \\
\text { dan } \\
\text { Metode }\end{array}$ & Hasil \\
\hline & & & & $\begin{array}{l}\text { adalah } \\
\text { tidak } \\
\text { ditentukan. } \\
\text { Perilaku anak- } \\
\text { anak diamati } \\
\text { lagi selama } \\
\text { pemberian infus } \\
\text { setelah } \\
\text { menerapkan } \\
\text { kembali terapi } \\
\text { bermain. Waktu } \\
\text { diantara kedua } \\
\text { sesi kurang dari } \\
48 \text { jam. } \\
\text { Anak-anak yang } \\
\text { termasuk dalam } \\
\text { penelitian ini } \\
\text { dirawat di } \\
\text { rumah sakit } \\
\text { setidaknya } \\
\text { selama } 24 \text { jam. }\end{array}$ & & & \\
\hline
\end{tabular}

Menurut tabel 1 sintesis grid, semua studi menggunakan permainan terapeutik untuk mempersiapkan anak-anak menjalani prosedur invasif. Berdasarkan 11 artikel yang ditelaah, semua studi menggunakan permainan terapeutik dengan mempersiapkan anak-anak yang akan menjalani prosedur invasif.

Berdasarkan dari hasil yang ditemukan, terdapat berbagai macam model terapi bermain misalnya terapi bermain dengan tehnik bercerita dimana didapatkan data bahwa sebelum intervensi, sebagian besar responden $(<60 \%)$ tidak kooperatif sedangkan setelah diberikan terapi bermain dengan teknik bercerita sebagian besar responden $(>60 \%)$ berperilaku kooperatif selama dalam perawatan (Apriani, 2017; Jafri, 2015; Andriany 2018). Terapi bermain instruksional seperti menggunakan boneka dan meminta anak untuk berpartisipasi mengulangi prosedur diperoleh data bahwa setelah intervensi, $>90 \%$ anak menjadi kooperatif dan kolaboratif selama tindakan prosedural (Santiago et al., 2016; Artilheiro et al., 2011).

Terapi bermain dengan mewarnai diperoleh data bahwa hampir seluruhnya $(78,6 \%)$ responden dengan tingkat kooperatif yang positif sesudah perlakuan terapi bermain (Purna et al, 2016). Selain itu, permainan lainnya yang digunakan selama dalam terapi adalah bermain boneka didapatkan tingkat kooperatif anak setelah intervensi menjadi 100\% (Elviani, 2019), sedangkan permainan dengan menggunakan ular tangga setelah intervensi diperoleh tingkat kooperatif anak sebesar 70,15\% 
Nur Rahmah, Tuti Seniwati, dan Bahtiar, Pengaruh Terapi Bermain terhadap Perilaku Kooperatif Anak Selama Tindakan Prosedur Invasif: Literature Review

Colin et al., 2020).

Penelitian Pontes et al (2015) menyebutkan bahwa sebelum diberikan tindakan prosedur invasif, reaksi yang paling sering terjadi pada anak adalah berteriak, mengatakan itu akan menyakitkan, dan menolak prosedur untuk menghindarinya sedangkan setelah dilakukan terapi bermain kelompok intervensi didapatkan mampu berkolaborasi secara spontan, merasa nyaman dan tersenyum

\section{PEMBAHASAN}

Dari artikel yang telah ditelaah menunjukkan bahwa anak-anak dalam kelompok eksperimen lebih kolaboratif dan menunjukkan lebih banyak reaksi penerimaan terhadap prosedur bila dibandingkan dengan kelompok kontrol. Dari hasil review ini, hasil uji beda pre dan post tes antara kelompok perlakuan dan kelompok kontrol diperoleh rata-rata nilai signifikan $(p)=<0,05$ yang artinya bahwa terdapat perbedaan yang signifikan perilaku kooperatif anak antara sebelum dan setelah pemberian terapi bermain.

Coyne (2006) mengungkapkan bahwa diperlukan tingkat kepekaan perawat terhadap emosi dan informasi yang dibutuhkan anak selama hospitalisasi. Hospitalisasi membuat anak menjadi cemas dan takut karena adanya beberapa faktor seperti pemisahan dari keluarga dan teman, berada pada lingkungan yang tidak dikenal, menerima prosedur tindakan/pengobatan, dan kehilangan jati diri. Komunikasi yang baik antara perawat dan anak dapat menurunkan stress selama di rumah sakit. Intervensi berupa terapi bermain dapat digunakan untuk menurunkan kecemasan pada anak selama masa hospitalisasi (Mulyanti \& Kusmana, 2018).

Beberapa materi dan strategi digunakan selama sesi bermain terapeutik. Namun dari hasil review dari sebelas artikel terapi bermain yang paling berpengaruh yaitu terapi bermain boneka dengan tingkat kooperatif responden didapatkan 100\%. Dalam Penelitian ini perempuan lebih banyak dibandingkan laki-laki (Elviani, 2019). Boneka merupakan mainan yang universal bagi anak perempuan, secara alami akan tertarik dengan bermain boneka yang menstimulasi pada anak (Montolalu, 2014).

Pengaruh terapi boneka dijelaskan oleh Pratiwi (2012) bahwa permainan dengan menggunakan alat bermain seperti boneka dapat menurunkan ketegangan emosional pada anak seperti kecemasan dan ketakutan selama di rawat di rumah sakit sehingga anak menjadi lebih percaya diri.

\section{SIMPULAN}


Karakteristik responden yang paling banyak ditemui dalam penelitian adalah perempuan dengan kelompok usia yang paling banyak yaitu pada umur 4 tahun.

Dari artikel yang telah ditelaah menunjukkan bahwa terapi bermain terbukti efektif terhadap perilaku kooperatif anak dan sebagian besar penelitian menemukan perubahan positif dalam perilaku tersebut dari anak-anak yang berpartisipasi dalam sesi bermain terapeutik, serta meningkatkan perilaku kooperatif selama dalam tindakan prosedural.

\section{SARAN}

Terapi bermain dapat diterapkan oleh perawat selama dalam perawatan anak khususnya dapat diberikan sebelum prosedur tindakan untuk mengurangi kecemasan dan ketakutan anak sehingga anak dapat kooperatif selama dalam pemberian tindakan keperawatan.

\section{DAFTAR PUSTAKA}

Andriany, A. (2018). Pengaruh terapi bermain terhadap tindakan kooperatif anak usia 3-5 tahun dalam menjalani perawatan di ruangan anak Rumah Sakit Pelamonia Makassar. Journal of Chemical Information and Modeling, 53(9), 1689-1699. https://doi.org/10.1017/CBO97811074 15324.004

Apriani, V. (2017). Terapi bermain terhadap perilaku kooperatif pada anak usia pra sekolah. Ilmu Keperawatan Indonesia,
7(3).

Artilheiro, A. P. S., De Amorim Almeida, F., \& Chacon, J. M. F. (2011). Use of therapeutic play in preparing preschool children for outpatient chemotherapy. ACTA Paulista de Enfermagem, 24(5), 611-616. https://doi.org/10.1590/s010321002011000500003

Bahris, S., Seniwati, T., \& Sangkala, Moh, S. (2020). Overview of post traumatic stress disorder ( ptsd ) symptoms of post-road. Indonesian Contemporary Nursing Journal, 5(1), 27-35.

Bucholz, E. M., Toomey, S. L., \& Schuster, M. A. (2019). Trends in pediatric hospitalizations and readmissions: 2010-2016. Pediatrics, 143(2), 20102016. https://doi.org/10.1542/peds.20181958

Colin, V., Keraman, B., Dwiana Maydinar, D., \& Eca. (2020). Volume 8 No. 1 (April 2020) (C) The Author(s) 2020 Pengaruh terapi bermain (. 8(1), 111-116.

Coyne, I. (2006). Children's experiences of hospitalization. Journal of Child Health Care, 10(4), 326-336. https://doi.org/10.1177/13674935060678 84

Elviani, Y. (2019). Pengaruh terapi bermain terhadap perilaku kooperatif anak selama menjalani perawatan di ruangan rawat inap Anak RSUD. Siti Aisyah Kota Lubuklinggau Tahun 2017. 7, 112120.

Handayani, \& Puspitasari. (2010). Pengaruh terapi bermain terhadap tingkat kooperatif selama menjalani perawatan pada anak usia prasekolah (3-5 tahun) di Rumah Sakit Panti Rapih Yogyakarta. Jurnal Kesehatan Surya Medika Yogyakarta.

Hockenberry, \& Wilson. (2007). Buku Ajar Keperawatan Pediatrik. Jakarta: EGC.

Jafri, Y. (2015). Pemberian terapi bermain dengan teknik bercerita terhadap kooperatif anak usia pra sekolah.

Kassam-Adams, N., \& Winston, F. K. (2004). Predicting child PTSD: The relationship between acute stress disorder and PTSD in injured children. 
Nur Rahmah, Tuti Seniwati, dan Bahtiar, Pengaruh Terapi Bermain terhadap Perilaku Kooperatif Anak Selama Tindakan Prosedur Invasif: Literature Review

Journal of the American Academy of Child and Adolescent Psychiatry, 43(4), 403-411. https://doi.org/10.1097/00004583200404000-00006

Koukourikos, K., Tzeha, L., Pantelidou, P., \& Tsaloglidou, A. (2015). The importance of play during. 27(November), $\quad 438-441$. https://doi.org/10.5455/msm.2015.27.4 38-441

Mairiza, P. (2015). Pengaruh terapi bermain terhadap perilaku kooperatif anak selama menjalani perawatan di ruangan rawat inap anak RSUD $M$. Zein Painan.

Marsac, M. L., \& Ph, D. (2017). A Qualitative analysis of children's emotional reactions during hospitalization following injury. 23(4), 194-201.

https://doi.org/10.1097/JTN.00000000 00000217.A

Montolalu, \& Dkk. (2014). Bermain dan permainan anak. Jakarta: Jakarta: Universitas Terbuka.

Mulyanti, S., \& Kusmana, T. (2018). Pengaruh terapi bermain terhadap tingkat kecemasan anak usia prasekolah akibat hospitalisasi Di RSUD Dr. Soekardjo Kota Tasikmalaya. Retrieved January 16, 2021, from Jurnal BIMTAS: Jurnal Kebidanan Umtas website: https://journal.umtas.ac.id/index.php/bi mtas/article/view/333/213

Ningrum, U., \& Nasrudin, N. (2015). Pengaruh terapi bermain kolase kartun terhadap tingkat kooperatif anak usia prasekolah selama prosedur nebulizer Di Rumah Sakit Airlangga Jombang. Jurnal EduHealth, 5(1), 244763.

Pontes, J. E. D. ourad., Tabet, E., Folkmann, M. Á. D. S. anto., Cunha, M. L. uca. da R., \& Almeida, F. de A. (2015). Therapeutic play: preparing the child for the vaccine. Einstein (São Paulo, Brazil), 13(2), 238-242. https://doi.org/10.1590/S167945082015AO2967
Pratiwi, Y. S. (2012). Penurunan tingkat kecemasan anak rawat inap dengan permainan hospital story di RSUD Kraton Pekalongan. Ilmiah Kesehatan, (5), 2.

Purna, Pramesti Pradira Triwahyu, Sawitri, Prihatini Monika, \& Yuliati, A. (2016). The influence of therapy play on the level of cooperative children. Pengaruh terapi bermain terhadap tingkat kooperatif anak usia prasekolah, 4(1), 65-72.

Santiago, Oliveira, Terapéutico, J., El, D., Punción, P. D. E., Para, E., Alteraciones, R., Fernandes, G. P. (2016). Therapeutic Toy During the Procedure of Venipuncture : a Strategy. 7(1).

Soetjiningsih. (2014). Tumbuh kembang anak. Jakarta: Penerbit Buku Kedokteran EGC.

Supartini. (2010). Konsep dasar keperawatan anak (Jakarta: E).

TAT, F., \& SING, S. A. (2014). Pengaruh terapi bermain alat kedokteran terhadap perilaku kooperatif dalam asuhan keperawatan anak usia pra sekolah di ruang anak RSUD Kefamenanu Kabupaten Timor Tengah Utara. Jurnal Info Kesehatan, 12(2), 710-721.

Terri, K., \& Susan, C. (2015). Buku ajar keperawatan pediatrik (2nd ed.). Jakarta: EGC. 